AL IBTIDA: JURNAL PENDIDIKAN GURU MI (2020) Vol 7 (2) : 280-294

DOI: http://dx.doi.org/10.24235/al.ibtida.snj.v7i2.7024

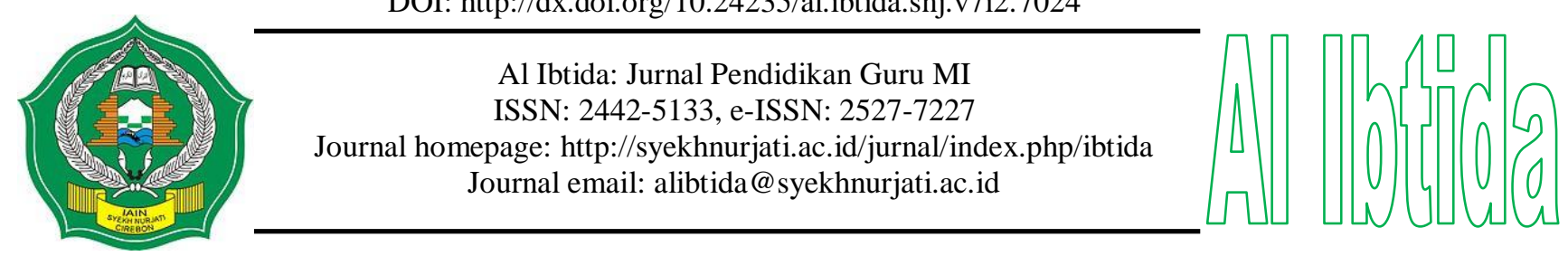

\title{
Improving the Ability of Understanding Mathematical Concepts through Digital-based Comics for Elementary School Students
}

\author{
Rida Fironika Kusumadewi* \\ *Department of Basic Education, Postgraduate Program, Universitas Negeri Jakarta, Indonesia. \\ *Primary Teacher Education Department, Faculty of Teacher Training and Education, \\ Universitas Islam Sultan Agung Semarang, Indonesia. \\ Email: ridafkd@unissula.ac.id
}

\author{
Amos Neolaka** \\ **Department of Basic Education, Postgraduate Program, Universitas Negeri Jakarta, Indonesia. \\ Email: amos_neolaka@yahoo.com \\ Mahmuddin Yasin*** \\ ***Department of Human Resource Management, Postgraduate Program, Universitas Negeri Jakarta/ \\ Universitas Krisnadwipayana, Indonesia. \\ Email: myasin.myconsulting01@gmail.com
}

Received: September $23^{\text {rd }}, 2019$. Accepted: October $18^{\text {nd }}, 2020$. Published: October $30^{\text {th }}, 2020$.

\begin{abstract}
This study was intended to improve the ability in understanding mathematical concepts through digital-based comics. The population in this study were the fifth grade elementary school students in the Genuksari area, Semarang, Indonesia, totaling 120 students, with sample of 58 students. The instrument used in this study was a test of the ability to understand mathematical concepts. Meanwhile, the research data were analyzed using different test (t-test) and normalized gain test. The results showed that the $\mathrm{t}$ test results showed $\mathrm{t}$-count $=39.74>\mathrm{t}$-table $=1.98$ at the significance level $\alpha=$ 0.05 . This means that the use of digital-based comic teaching materials is better than conventional books. Meanwhile, the results of the n-gain test showed that the pretest value was 61.17 and the posttest value was 90.96 with an average value of 0.73 increase in the high category. So, it can be concluded that the teaching materials developed could increase students' ability to understand mathematical concepts. Therefore, the use of teaching materials digital-based comics is very effective and becomes an alternative in increasing the ability to understand mathematical concepts in elementary school students.
\end{abstract}

Keywords: teaching materials, digital comics, ability to understand mathematical concepts. 


\begin{abstract}
Abstrak
Penelitian ini bertujuan untuk meningkatkan kemampuan pemahaman konsep matematika melalui komik berbasis digital. Populasi dalam penelitian ini adalah siswa kelas lima sekolah dasar di wilayah Genuksari, Semarang, Indonesia yang berjumlah 120 siswa, dengan sampel 58 siswa. Instrumen yang digunakan dalam penelitian ini berupa tes kemampuan pemahaman konsep matematika. Sementara itu, data hasil penelitian dianalisis menggunakan uji beda (t-tes) dan uji gain ternormalisasi. Hasil penelitian menunjukkan bahwa hasil uji t menunjukkan $\mathrm{t}$-hitung $=$ $39,74>\mathrm{t}$-tabel $=1,98$ pada taraf signifikansi $\alpha=0,05$. Artinya penggunaan bahan ajar komik berbasis digital lebih baik dari buku konvensional. Sedangkan hasil uji n-gain diperoleh bahwa nilai pretest sebesar 61,17 dan nilai posttest sebesar 90,96 dengan nilai rata-rata peningkatan sebesar 0,73 dengan kategori tinggi. Sehingga dapat disimpulkan bahan ajar yang dikembangkan dapat meningkatkan kemampuan pemahaman konsep matematika siswa. Oleh karena itu, penggunaan bahan ajar komik berbasis digital sangat efektif dan menjadi alternatif dalam meningkatkan kemampuan pemahaman konsep matematika pada siswa sekolah dasar.
\end{abstract}

Kata kunci: bahan ajar, komik digital, kemampuan pemahaman konsep matematika.

\title{
INTRODUCTION
}

Many components are involved in learning, one of which is teaching materials. Teaching materials are used to assist teachers/lecturers/instructors in carrying out teaching and learning activities in class. Teaching materials are information, tools, and texts needed by teachers or instructors for planning and reviewing learning implementation (Guntur et al., 2017). In line with technological advances, teaching materials can be printed and non-printed materials, meaning that the potential of the technology can be a powerful tool for transforming learning. Because, the challenges of education in the 4.0 era are the challenges of education in the digital era (Supriatna et al., 2020). So that, educators have the responsibility to prepare for the use of technology and assess the impact of using technology on children in the learning process. Therefore, digital teaching materials are very important to use in the learning process (Muhdi \& Buchori, 2017).

Delivery of information usually occures during learning instruction, where it needs tools to convey information or material. These information delivery tools are called learning media. Munyengabe et al., (2017) in his research stated that the skills of teachers on technology in developing instructional media are needed. Today's, media is indispensable and very effective in leveraging several abilities. The use of technology in the 21 st century is a habit that allows children to develop and be able to improve students' competencies (Hobbs \& Moore, 2013). One of them is digital comics. The messages conveyed in comics are in the form of images and writing in the form of a series of stories that are able to provide a more concrete and real picture so that they can attract students' attention and interest in learning. Through the comics 
media, students will easer to remember the material (Maufur \& Lisnawati, 2017) and improving student competence (Fatimah \& Widiyatmoko, 2019).

Comics as a teaching material certainly has its own advantages for its readers/students. Triono (2014) in his research stated that digital comic teaching materials have several advantages including (1) digital comic teaching materials are more durable than printed comics teaching materials; (2) making digital comic teaching materials cheaper and more efficient because printing does not need to be done. However, it does not rule out that users of digital comic teaching materials can also print comic teaching materials; (3) for teachers, digital comic teaching materials will be easier to distribute to students, namely through laptops or computers. This is also reinforced by Amin et al. (2017) who stated that through the dialogue structure of mathematics, comics helps students understand the material as well as get value planting. This is because comics have coherent and orderly storylines that makes it easy to remember. Along with the development of technology, comics are not only in the form of printed materials but can also be in digital form. The development of comic teaching materials is currently being developed a lot, but teaching materials in the form of digital comics are still limited.

According to Waluyanto (2005) in terms of the function aspect, explains that the engineering of learning comics, it will appear that something serious and complex can be made in a clear and fun way. With digital comic teaching materials, mathematics learning in schools is expected not only to be limited to taking notes and doubting the truth, but students are also able to grasp the meaning of learning from the teaching materials they read (Fajar et al., 2019). Digital comic teaching materials can improve several aspects of learning, one of which is the cognitive aspect. Hidayat et al. (2019) in his research developed a webtoon comic teaching material where the teaching material is used in the learning process in two directions, namely teaching materials as a tool that can also be used as student learning media. Prasetyo (2017) explaining interactive and interesting learning can increase student enthusiasm and achievement, namely by using android-based digital comics.

From several existing studies, what is new in this research is that the development of digital-based comic teaching materials is very effective in the learning process. Refers to research on Sagri et al. (2018), there is still a lack of learning using digital, on the other hand, that digital learning makes students interested in the learning to be delivered. Anggoro et al. (2012) explained that the cognitive aspects of children are influenced by verbal and visual information which will have an impact on learning. According to Prasetyo (2017), in the results of his research that the increase in the ability to understand mathematical concepts is 
influenced by discovery learning based on the Toba culture. Some of the problems that overwhelm students in math problems are the low level of mathematical understanding and mathematical reasoning. The results of the analysis of the difficulty of the test questions based on one of the indicators used were in the communication aspect, that the results of the analysis carried out had significant potential to increase students' understanding of the questions they were doing (Prasetyo, 2017). In addition, based on the research results of Kurniawati et al. (2017) revealed that in the cognitive aspect, the average learning rate is the lowest compared to other aspects, the digital comic teaching materials in this study are used to improve the cognitive aspects, namely the ability to understand students' mathematical concepts.

According to Anderson \& Krathwohl (2001), the teacher prioritizes more in the transfer of knowledge, so the teacher must consider various categories of cognitive processes including interpreting factual knowledge, explaining conceptual, executing procedural knowledge, differentiating conceptual knowledge, examining procedural knowledge, criticizing metacognitive knowledge and objectives, and to generate conceptual knowledge. This is because mathematics is an order of organized structure, mathematical concepts that are arranged hierarchically and systematically, starting from the simplest concepts to complex concepts. In the concept of geometry, students are required not only to be able to distinguish these shapes but also to see the relationship between geometric concepts through their understanding (Mawaddah \& Maryanti, 2016). Understanding the concept leads students to learn mathematics actively and build on previous knowledge and experience. Indicators of the ability to understand the concepts described in the study (Suraji et al., 2018). There are three indicators used, namely restating a concept and classifying objects according to the concept; presents concepts in various forms of mathematical representation, using, utilizing, selecting specific procedures or operations, and applying concepts.

From the results of observations and interviews with the principal of SD (elementary school) Muktiharjo Lor, Genuk District, Semarang City on December 18, 2019, he stated that the low mathematics score on the results of the mathematics exam was because students still could not observe the questions which are being tested. This is proven when students are given exercises before facing exams, students still feel confused in the process. Besides, students still do not know the various meanings and relationships between different topics in mathematics, for example, students are often wrong when determining the formula between the volume of space with a broad approach. Another factor that appears is the enthusiasm of students in working on the questions is still very low and students often do not take advantage of objects around them in working on these questions. In addition, running with the 
development of knowledge and technology in the era of globalization, teachers are strived to develop their potential through various training and seminars held by several institutions. It is also emphasized in research Jannah, Prasojo \& Jerusalem (2020) that digital literacy needs special attention that must be developed by educators so that it can balance the tendencies of the characteristics possessed by students.

Based on the description of the results of the need analysis above, it is necessary to carry out new research and innovations that would be developed through digital-based comic media. The types of teaching materials developed through comic media can be installed on Android phones both online and offline mode. This study was intended to improve the ability to understand mathematical concepts through digital-based comics.

\section{METHODS}

This study applies a development research approach and method (Research and Development. This research was conducted at an elementary school in the Genuksari area of Semarang, Indonesia which consisted of 3 schools with each school taking 1 class as the experimental class and the control class. The subjects of this study were 58 people from the experimental class and 54 from the control class.

The development stage of digital comic mathematics teaching materials was designed using the research and development of the Brog and Gall model and the Instructional Development Model (MPI). The results of the adaptation of teaching material development start from preliminary studies, development, validation, testing, and implementation of teaching materials. The teaching material design is developed into five steps. First, the preliminary study stage is to conduct literature studies and field studies. Second, the development of teaching materials is to compile digital-based comic learning materials for mathematics. Third, the validation of teaching materials by experts is to assess the feasibility of teaching materials by involving several experts according to their respective areas of expertise. Fourth, the trial of teaching materials is to assess the feasibility of digital comic teaching materials for users, namely students and teachers. The trial was carried out 3 times, namely one-on-one trials, small scale, and large scale. Fifth, the implementation of teaching materials is to use teaching materials through digital comic media in real learning. The implementation uses the experimental class design and the control class. The experimental and control class includes three schools located in the Genuksari area.

In this research, the development used is in the validation stage of teaching materials developed by experts related to the feasibility of teaching materials, secondly, testing the teaching materials by assessing the appropriateness of teaching materials through comics to 
users, third is the implementation of the teaching materials developed. The research was conducted using research and development methods so that the subjects involved were adjusted based on the stages of teaching material design. The subjects during the validation of teaching materials were 3 learning design experts, 3 mathematics material experts, and 3 peer experts. The subjects during the trial of teaching materials were 10 students (one-on-one trial), 20 students (small-scale trial), and 58 students (large-scale trial). The subjects during the implementation of the model were 58 students.

The research data consisted of expert validation data, teaching material trial data, and teaching material implementation data. Data sources include teachers, students, image and graphic design experts, material experts, and language experts. Data were collected using questionnaire guidelines, tests, and observation sheets. The research instrument used a questionnaire consisting of an instrument for assessing teaching material products by experts and an instrument for product assessment by teachers and students as users. In addition, there is a test instrument to measure students' understanding of mathematical concepts in the form of multiple-choice as many as 25 items. In making the problem of understanding mathematical concepts, the researcher uses operational verbs in Bloom's taxonomy where each thinking skill has different characteristics of the problem according to the indicator on the ability to understand mathematical concepts.

Before being tested, the questionnaire was calculated using the CVR formula, with the criteria for assessing CVR $<0$ then having bad criteria, CVR $=0$ having unfavorable criteria, and $\mathrm{CVR}>0$ with good criteria. The results of the evaluation of the material expert validation obtained an average value of 3.16 with a good predicate, an average value of 5.75 for the results of peer validation with a good predicate. All results of expert judgment have instrument criteria suitable for use.

The data analysis technique of the students' mathematical concept understanding test results used inferential statistics. The test steps are: first, conducting a normality test to see whether the data group comes from a normally distributed population; second, performing a homogeneity test to see whether the data groups have the same variance; third, doing the t-test (difference test) and gain test to see the effectiveness of using digital comic teaching materials by students in the class. 


\section{RESULTS AND DISCUSSION}

This study presents the results of the development and implementation of digital-based comic teaching materials to improve the ability to understand math concepts in fifth-grade elementary school students. The process of using the developed teaching materials begins with a validation test by experts, namely material experts, and colleagues, each aspect involves 3 experts in each field of expertise. The objective of the expert's assessment is to assess the appropriateness of comic teaching materials in terms of content, material presentation, legibility or language, layout, and animation. After that, continued with the user trial, namely the students. The aim of the procedure was to see the feasibility of teaching materials from the user's point of view.

The assessment from the material expert team aims to see the quality in terms of mathematics material in the teaching materials that have been developed. The assessment of the material expert panel team consisted of 35 questions and the results of the analysis showed that each item was in a good category with a CVR value of 3.16 and was declared fit for use with a slight revision. There are some suggestions, however. The suggestions include: (1) the letters listed on the ribs are not clearly visible; (2) mention of the long ribs when indicating the number of ribs; (3) laying down basic competencies at the beginning; (4) cover is added to the digital teaching materials; (5) adding a glossary and author's biography.

The suggestions from the material expert team were taken into consideration for revisions. The suggestions were first, revising the display color on the ribs so that they are clearly visible; the second, eliminating the long word when mentioning the word; the third, putting the basic content at the beginning, which originally lies behind; the fourth, adding a glossary and author's biography to the digital teaching materials.

The peer assessment aims to further refine the initial teaching material products that have been developed. The peer panelist team's assessment numbered 35 items with an average value of $\mathrm{CVR}=5.75$ and was declared feasible to use with a slight revision based on the suggestions given. The suggestions include: (1) adding pages. (2) Adding audio to the material explanation; (3) A video is made at the conclusion and given a background on the conclusion.
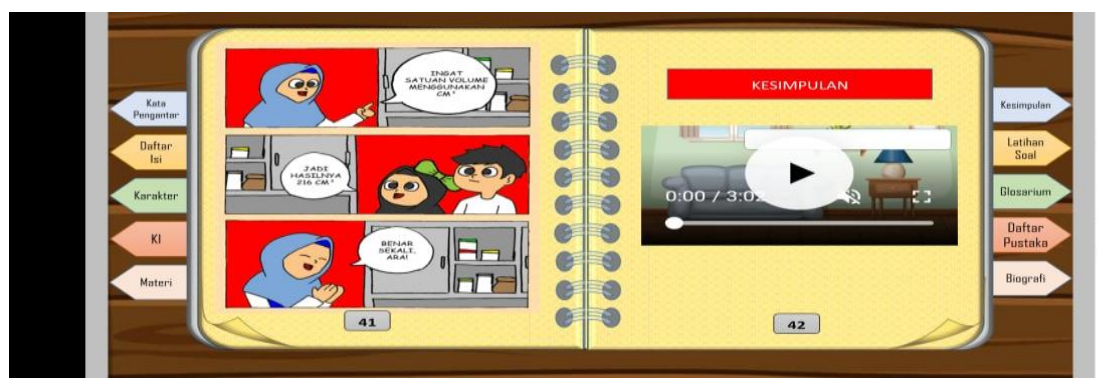

Figure 1. Display of teaching materials based on input from peers 
Figure 1 shows the improvements that have been corrected based on suggestions from the peer panelist team. The suggestion was about revision by adding pages to the comic teaching material so that it is easy to understand when students read digital comic teaching materials. Second, recording to add audio to the material that has been delivered. The goal is to make students' ability to understand the material better. Third, by making a video on the conclusion display with the aim, so that the teaching material displayed is not monotonous and has an attraction for students. The need for the development of digital comic media that is in accordance with the development of modern science and technology because digital comic media has kept up with the times and its use makes it easier for students (Raneza \& Widowati, 2020). In line with the statement Ntobuo (2018), children including elementary school students, generally like illustrations and comics because they think it entertains them in reading as well as can unwittingly provide information related to the material they are learning.

The second step is testing the teaching materials that have been developed. This trial was carried out in two elementary schools, each school consisting of 5 students and 1 teacher so that there were 10 students and 2 class V teachers. Assessment was conducted by the appointed time. The element of the trial assessment consists of 13 statements filled in by students. The data for the one-on-one trial assessment by students were analyzed using the Lawshe formula to determine the content validity ratio (CVR), which means the value of the content validity ratio with category (1) if the value of CVR $<0$ then the item is declared not good; (2) if the value of CVR $=0$ then the item is declared unfavorable; (3) if the value of CVR> 0 then the item is declared as good. The trial data is presented in the table below:

Table 1. Results of One-on-One Trials by Students Against Usage Teaching Materials through Digital Comics

\begin{tabular}{|c|c|c|c|c|c|c|c|c|c|c|c|c|c|}
\hline \multirow[b]{2}{*}{ Statistik } & \multicolumn{13}{|c|}{ Item } \\
\hline & 1 & 2 & 3 & 4 & 5 & 6 & 7 & 8 & 9 & 10 & 11 & 12 & 13 \\
\hline $\mathrm{Mp}$ & 9 & 10 & 9 & 9 & 10 & 10 & 9 & 10 & 10 & 9 & 9 & 10 & 10 \\
\hline M & 10 & 10 & 10 & 10 & 10 & 10 & 10 & 10 & 10 & 10 & 10 & 10 & 10 \\
\hline CVR & 0,8 & 1 & 0,8 & 0,8 & 1 & 1 & 0,8 & 1 & 1 & 0,8 & 0,8 & 1 & 1 \\
\hline Inform. & \multicolumn{13}{|c|}{ WELL } \\
\hline
\end{tabular}

Based on table 1, the results of the one-to-one test by 10 students with 13 questions, show that the teaching materials developed with a CVR value> 0 means that the teaching materials developed are good and have criteria suitable for use. In addition, one-on-one trials by teachers who were tested on 3 teachers got an average CVR value of $0.94>0$ with good criteria and the teaching materials were feasible to implement. 
After the one-on-one trials were carried out, the next trial step was small group scale trials. This trial was carried out in four elementary schools, each school consisting of 5 students and 1 teacher so that there were 20 students and 4 class $\mathrm{V}$ teachers. the appointed time. The element of the trial assessment consists of 13 statements filled in by students. The results of the small group trial were, the mean value of CVR $=0.82>0$ means that the teaching materials tested on a small group scale were good and feasible to be implemented.

The next step is the implementation of the teaching materials developed to determine the ability of elementary school students to understand mathematical concepts. One of the most important student abilities in aspects that can affect learning outcomes is the ability to understand a concept (Huda et al., 2019). The testing step in the first study conducted a normality test to see whether the data group came from a normally distributed population. Second, perform a homogeneity test to see whether the data groups have the same variance. Third, conduct a t-test (different tests) to see the effectiveness of using digital comic teaching materials by students in the classroom. A different test (t-test) is used to see the comparison of the two sample averages in the study, which means comparing the effectiveness of the developed model with the ongoing/conventional model. The results of the t-test calculation of the ability to understand mathematical concepts in the experimental class and control class are presented below:

Table 2. The results of t-test data on the ability of students to understand mathematical concepts in the experimental and control classes.

\begin{tabular}{lll}
\hline Statistic & Experiment Class & Control Class \\
\hline Number of samples (N samples) & 58 & 54 \\
Average (Average) & 22,74 & 8,46 \\
Standard Deviation (AND) & 1,74 & 2,03 \\
Difference & 3,04 & 4,14 \\
$\mathrm{~T}_{\text {count }}$ & 39,74 & \\
$\mathrm{~T}_{\text {table }}(\alpha=0.05)$ & 1,98 & \\
\hline
\end{tabular}

Based on table 2, the results of the t-test on the students' ability to understand mathematical concepts show that $\mathrm{t}_{\text {count }}=39.74>\mathrm{t}$ table $=1.98$ at the significance level $\alpha=$ 0.05 , then $\mathrm{H}_{0}$ is rejected and accepts $\mathrm{H}_{1}$. The average concept comprehension ability test in the experimental class was 22.74 with the highest score of 100 and the lowest score 92, while the average for the control class was 8.46 with the highest score getting a score of 70 and the lowest score being 45 . So it can be concluded that the test results in the ability to understand mathematical concepts from the experimental group were higher than the control group (which means that users of digital-based comic teaching materials were better than conventional books in increasing students' ability to understand mathematical concepts). The 
results of the test of the ability to understand mathematical concepts on the indicator linking conceptual and procedural knowledge by defining the concept verbally have a process range in the experimental class and the control class of 0.694 .

Comics can be said to be a good learning media in increasing student competence if the teaching materials through comics meet the material indicators taught from each material being told, namely by loading learning materials in accordance with the subject matter of the material to be given (Wijayanti et al., 2018). Meanwhile, according to Talib et al. (2005) Conceptual change in students is a learning process that needs to be improved through the use of animated images on computers. Talib et al. (2005) argued that the visualization feature is a positive feature used in the learning process. Digital content provides increased interactivity between students and curriculum materials (Choppin, J., et.al., 2014). In line with this Yigit (2014) also reveals that increased use of technology can improve mathematics teaching in the future. From several research exposures that are in line with research conducted by researchers, teaching materials through digital-based comics are teaching materials which contain stories that describe the material presented, besides that there is a visualization of the teaching material accompanied by videos or interactive images which written on teaching materials through digital-based comics, so as to increase the ability of fifth-grade students to understand mathematical concepts.

Increased conceptual understanding of the teaching materials developed is measured based on several indicators. The results of the first indicator analysis, namely using known facts and relationships to explain students' thoughts, obtained a percentage difference of 0.436. In the first indicator, students describe the cubic space and cube nets very well, besides that students already understand the elements in space, besides that students, can also distinguish between cube space shapes and other spatial shapes. In line with research Auzar (2018) that the ability to understand the language in math problems is related to the ability to read for understanding because both require the ability to understand a text. If students do not understand the text, it means they cannot explain the text, for example, to complete the problem items described in math problems.

The second indicator is using known fact models and relationships to explain students' thinking. Where on the second indicator students are able to communicate the questions they read with their thoughts, meaning that students must be able to process story problems into math sentences in the language they understand. Students are able to determine the volume of the shape through the base area approach, unit cube and students are able to describe the questions which are then converted into mathematical sentences. However, in this second 
indicator, there is an attainment of the same percentage, namely that in the control class and the experimental class, students can equally determine the volume of the shape through the base area and unit cube approach. Even so, on the second indicator, the percentage in the experimental class still shows higher results than in the control class.

Purnama et al. (2015) shows that the student's ability to understand mathematical concepts is still low, as evidenced by the low percentage of achievement of each indicator. The results of this study can provide information to lecturers about the ability of students to understand mathematical concepts so that lecturers are expected to be able to design learning activities that can improve students' ability to understand mathematical concepts. Through interesting learning media, students can learn in a fun way and the learning that is created is also more meaningful. Fun and meaningful learning results in increased student learning achievement (Purnama \& Mulyoto, 2015). One of the learning media used is learning media that can streamline the limited learning time, overcome students' visualization skills about human and environmental relationship text material (Kustianingsari \& Dewi, 2015).

It is also supported by Ruiyat, Yufiarti \& Karnadi (2019), who underlined that speaking skills are one of the language developments that are developed in early childhood, as a communication tool and a means to express what students feel. Thematic electronic comics can improve speaking skills in children. Besides, the meaning of learning for children will be rooted strongly as shown when children recount their previous learning activities. Comic characters that visualize stories, are seen as understandable by students, and also make it possible to connect scientific assignments with authentic situations taken from students' lives (Affeldt, 2018). Comics are very efficient in communicating and very effectively used in learning because they allow students to absorb learning concepts (Kurniawati, 2017).

According to Dewantara (2020), he revealed that the need for practice in communicating in accordance with current education. Basic skills that need to be mastered by students are communication skills (Prabowo \& Ariani, 2018). Comics are more effective in retaining the knowledge to communicate verbally obtained by students (Zhang-Kennedy, Baig, \& Chiasson, 2017). In line with research (Ariyanto \& Laksana, 2019) educational comics are expected to contribute to the world of education. It is also emphasized in research (Arini, Choiri \& Sunardi, 2017) that through comics students can combine text with visual representations while teaching students as well as increase student attention and participation because of the novelty of what they write. 
Rida Fironika Kusumadewi, Amos Neolaka, Mahmuddin Yasin, Improving the Ability of Understanding...

\section{CONCLUSION}

The results showed that the increase in the ability to understand mathematical concepts was depended on the teaching materials they read. The development of mathematics teaching materials through comic media makes it easier for students to receive the material presented. Mathematics teaching materials through digital comic media have an impact on increasing the ability to understand mathematical concepts. This research recommends an idea of delivering mathematics material through digital-based comic media packaged in mathematics teaching materials. The results of this study have implications for the development trend of the $21 \mathrm{st}$ century and the development of competencies in digital skills, one of which is by promoting student characteristics. It is hoped that further research can develop digital-based mathematics teaching materials on other materials with the aim of introducing digital literacy in the world of education so that they can compete globally.

\section{REFERENCES}

Affeldt, F., Meinhart, D., \& Eilks, I. (2018). The use of comics in experimental instructions in a non-formal chemistry learning context. In International Journal of Education in Mathematics, Science and Technology (Vol. 6, Issue 1, pp. 93-104). https://doi.org/10.18404/ijemst.380620

Amin, M. M., Hartono, Y., \& Nyimas, A. (2017). Pengembangan Media Komik Matematika Berbasis Nilai Karakter pada Materi Trigonometri di Kelas X SMA Negeri 1 Indralaya Utara. Jurnal Elemen, 3(1), 35. https://doi.org/10.29408/jel.v3i1.305

Anderson, L.W., Krathwohl, D.R., (2001). A Taxonomy for Learning, Teaching, and Assessing: ARevision of Bloom's of Educational Objectives.

Anggoro, F. K., Stein, N. L., \& Jee, B. D. (2012). Cognitive factors that influence children's learning from a multimedia science lesson. International Electronic Journal of Elementary Education, 5(1), 93-108.

Arini, F. D., Choiri, A. S., \& Sunardi. (2017). The Use of Comic As a Learning Aid To Improve Learning Interest of Slow Learner Student. European Journal of Special Education Research, 2(1), 71-78. https://doi.org/10.5281/zenodo.221004

Ariyanto, A., \& Laksana, S. D. (2019). Learning Social Sciences With Comic Strip.

Auzar, M. S. (2018). The Relationships of Reading Comprehension Ability with the Ability to Understand The Questions of Mathematical Word Problems. Mediterranean Journal of Social Sciences, 8(4-1), 145-151. https://doi.org/10.2478/mjss-2018-0084

Choppin, J., Carsons, C., Bory, Z., Cerosaletti, C., \& Gillis, R. (2014). (2014). A typology for analyzing digital curricula in mathematics education. International. International Journal of Education in Mathematics, Science and Technology, 2(2), 11-25.

Dewantara, D. (2020). The influence of educational comics on the concept of static electricity toward student's learning outcomes and communication skills. Thabiea : Journal of Natural Science Teaching, 3(1), 20. https://doi.org/10.21043/thabiea.v3i1.6894

Fajar, A. P., Kodirun, K., Suhar, S., \& Arapu, L. (2019). Analisis Kemampuan Pemahaman 
Konsep Matematis Siswa Kelas VIII SMP Negeri 17 Kendari. Jurnal Pendidikan Matematika, 9(2), 229. https://doi.org/10.36709/jpm.v9i2.5872

Fatimah, F., \& Widiyatmoko, A. (2019). Pengembangan Science Comic Berbasis Problem Based Learning Sebagai Media Pembelajaran Pada Tema Bunyi dan Pendengaran Untuk Siswa SMP. Jurnal Pendidikan IPA Indonesia, 8(1), 52-62.

Gall, M. D., Gall, J. P., \& Borg, W. R. (2014). Applying educational research: How to read, do, and use research to solve problems of practice. Pearson Higher Ed.

Gaudreau, C. M., Anggoro, F. K., \& Jee, B. D. (2020). Children's Spontaneous Gestures Reflect Verbal Understanding of the Day/Night Cycle. Frontiers in Psychology, 11(June), 1-7. https://doi.org/10.3389/fpsyg.2020.01123

Guntur, M., Muchyidin, A., \& Winarso, W. (2017). Pengaruh Penggunaan Bahan Ajar Matematika Bersuplemen Komik Terhadap Kemandirian Belajar Siswa. Eduma, 6(1), 43-51.

Hidayat, N., Rostikawati, R. T., \& Marris, M. H. (2019). Pengembangan Bahan Ajar Komik Webtoon Untuk Meningkatkan Hasil Belajar Biologi Siswa SMA Kelas XI. Prosiding Seminar Nasional SIMBIOSIS IV, 318-324.

Hobbs, R., \& Moore, D. C. (2013). Discovering media literacy: Teaching digital media and popular culture in elementary school. Corwin Press.

Huda, S., Anggraini, L., Saputri, R., Syazali, M., Umam, R., Islam, U., \& Radenintan, N. (2019). Learning Model to Improve The Ability to Understand Mathematical Concepts. Prisma, 8(2), 173-181.

Jannah, M., Prasojo, L. D., \& Jerusalem, M. A. (2020). Elementary School Teachers' Perceptions of Digital Technology Based Learning in the 21st Century: Promoting Digital Technology as the Proponent Learning Tools. Al Ibtida: Jurnal Pendidikan Guru MI, 7(1), 1. https://doi.org/10.24235/al.ibtida.snj.v7i1.6088

Kurniawati, A. A., Wahyuni, S., \& Putra, P. D. A. (2017). Utilizing of Comic and Jember's Local Wisdom as Integrated Science Learning Materials. International Journal of Social Science and Humanity, 7(1), 47-50. https://doi.org/10.18178/ijssh.2017.7.1.793

Kustianingsari, N., \& Dewi, U. (2015). Pengembangan Media Komik Digital Pada Mata Pelajaran Bahasa Indonesia Tema Lingkungan Sahabat Kita Materi Teks Cerita Manusia dan Lingkungan Untuk Siswa Kelas V SDN Putat Jaya III/379 Surabaya. Jurnal Mahasiswa Teknologi Pendidikan, 6(2), 1-9.

Maufur, S., \& Lisnawati, S. (2017). Pengaruh Penggunaan Media Gambar Berseri Terhadap Keterampilan Berbicara Bahasa Indonesia Siswa Kelas III MI Al-Washliyah Perbutulan Kabupaten Cirebon. Al Ibtida: Jurnal Pendidikan Guru MI, 4(2), 189. https://doi.org/10.24235/al.ibtida.snj.v4i2.1888

Mawaddah, S., \& Maryanti, R. (2016). Kemampuan Pemahaman Konsep Matematis Siswa SMP dalam Pembelajaran Menggunakan Model Penemuan Terbimbing (Discovery Learning). EDU-MAT: Jurnal Pendidikan Matematika, 4(1), 76-85. https://doi.org/10.20527/edumat.v4i1.2292

Muhdi, M., \& Buchori, A. (2017). The Development of Digital Media Book as a Supplement Material for Human Resources management Course Lesson. Asian Journal of Information Technolgy, 16(6), 493-497.

Munyengabe, S., Yiyi, Z., Haiyan, H., \& Hitimana, S. (2017). Primary teachers' perceptions 
on ICT integration for enhancing teaching and learning through the implementation of one Laptop Per Child program in primary schools of Rwanda. Eurasia Journal of Mathematics, Science and Technology Education, 13(11), 7193-7204. https://doi.org/10.12973/ejmste/79044

Ntobuo, N. E., Arbie, A., \& Amali, L. N. (2018). The development of gravity comic learning media based on gorontalo culture. Jurnal Pendidikan IPA Indonesia, 7(2), 246-251. https://doi.org/10.15294/jpii.v7i2.14344

Prabowo, C. A., \& Ariani, N. L. (2018). Meningkatkan Keterampilan Komunikasi Oral Mahasiswa Melalui Strategi Pembelajaran Think Pair Share. BIOEDUKASI (Jurnal Pendidikan Biologi), 9(1), 57. https://doi.org/10.24127/bioedukasi.v9i1.1384

Prasetyo, A. A. (2017). Komik Digital Berbasis Android ( M- Learning ) Dalam Pembelajaran Sejarah untuk Meningkatkan Kesadaran Budaya. Jurnal Sisfokom (Sistem Informasi Dan Komputer), 316-327.

Purnama, U. B., Mulyoto, \& Ardianto, D. T. (2015). Penggunaan Media Komik Digital Dan Gambar Pengaruhnya Terhadap Prestasi Belajar Ipa Ditinjau Dari Minat Belajar Siswa. Teknodika, 13(2), 18-28.

Raneza, F., \& Widowati, H. (2020). Analisis Urgensi Pengembangan Komik Digital Dengan Mengintegrasikan Nilai-Nilai Keislaman. Biolova, 1(1), 13-18.

Ruiyat, S. A., Yufiarti, Y., \& Karnadi, K. (2019). Peningkatan Keterampilan Berbicara dengan Bercerita Menggunakan Komik Elektronik Tematik. Jurnal Obsesi : Jurnal Pendidikan Anak Usia Dini, 3(2), 518. https://doi.org/10.31004/obsesi.v3i2.256

Sagri, M., Sofos, F., \& Mouzaki, D. (2018). Digital Storytelling, comics and new technologies in education: Review, research and perspectives. International Education Journal, 17(4), 97-112.

Skemp, R. R. (1962). The Need for a Schematic Learning Theory. British Journal of Educational Psychology, 32(P2), 133-142.

Supriatna, T., Matahari, M., \& Ihsan, M. (2020). Pengembangan Lembar Kerja Peserta Didik Berbasis Komik Digital Pada Materi Sistem Bilangan Mata Pelajaran Sistem Komputer Kelas X. JURNAL PETISI (Pendidikan Teknologi Informasi), 1(2), 48-58.

Suraji, Maimunah, \& Sehatta, S. (2018). Analisis Kemampuan Pemahaman Konsep Matematis dan Kemampuan Pemecahan Maslah Matematis Siswa SMP Pada Materi Sistem Persamaan Linier Dua Variabel (SPLDV). Suska Journal of Mathematics Education, 4(1), 9-16. https://doi.org/10.24014/sjme.v3i2.3897

Talib, O., Matthews, R., \& Secombe, M. (2005). Computer-animated instruction and students' conceptual change in electrochemistry: Preliminary qualitative analysis. Nternational Education Journal, 5(5), 29-42.

Triono, J. (2014). Pengembangan Bahan Ajar Akuntansi Berbentuk Komik Digital. Jurnal Pendidikan Akuntansi (JPAK), 2(2), 1-6.

Tyas, F., Pangesti, P., \& Retnowati, E. (2017). Pengembangan Bahan Ajar Geometri SMP Berbasis Cognitive Load Theory Berorientasi pada Prestasi Belajar Siswa Developing Geometry Learning Materials for Junior High School Based on Cognitive Load Theory With Regard to Student's Achievement. Pythagoras: Jurnal Pendidikan Matematika, 12(1), 33-46.

Waluyanto, H. W. (2005). Komik Sebagai Media Komunikasi Visual Pembelajaran. Nirmana, $7,45-55$. 
Wijayanti, R., Hasan, B., \& Loganathan, R. K. (2018). Media comic math berbasis whiteboard annimation dalam pelajaran matematika. Jurnal Riset Pendidikan Matematika, 5(1), 53. https://doi.org/10.21831/jrpm.v5i1.19207

Yigit, M. (2014). A Review of the Literature: How Pre-service Mathematics Teachers Develop Their Technological, Pedagogical, and Content Knowledge. International Journal of Education in Mathematics, Science and Technology, 2(1), 26-35. https://doi.org/10.18404/ijemst.96390

Zhang-Kennedy, L., Baig, K., \& Chiasson, S. (2017). Engaging children about online privacy through storytelling in an interactive comic. HCI 2017: Digital Make Believe Proceedings of the 31st International BCS Human Computer Interaction Conference, HCI 2017, 2017-July, 1-11. https://doi.org/10.14236/ewic/HCI2017.45 